\title{
DISCIPLINARY ACTIONS AND PROCEDURES AT WORKPLACE: THE ROLE OF HR MANAGERS
}

\author{
UGO CHUKS OKOLIE \\ IDONGESIT DAVID UDOM
}

\begin{abstract}
Organisational discipline arises out of the need for management to be able to control the conduct of employees and to re-direct their energies towards the attainment of corporate mission and objectives. Discipline is management action that encourages and ensures compliance with laid-down rules and regulations, governing the smooth operation of an organisation. It is management's responsibility to develop and maintain effective discipline within the organisation. As in most peoples' management functions, HR managers have an extremely important role to play in the design and implementation of disciplinary procedures that are fair to all, and that cases of discipline are dealt with in accordance with the organisation's laid-down procedures. For the purpose of this article, reinforcement theory attributed to Skinner (1974), form the theoretical framework for this article. This article examines the nature of discipline, the causes of disciplinary action, the importance of disciplinary procedures and the role of HR managers in discipline handling. The article further takes a peep into the impact of objective disciplinary measures on employees' performance. The article therefore, concludes that for discipline to be a means of correcting or punishing misdeed in an organisation, management must learn to maintain discipline by applying standards in a consistent, fair and flexible manner.
\end{abstract}

Keywords: Discipline, Action, Procedure, Role, HR Managers, Employee Performance

JEL code: M2, M52, M54, H55

\section{INTRODUCTION}

Organisation involves bringing people together to achieve defined goals and objectives. In such an organisation, however good the management and however highly motivated the workforce, there will be occasions when problems or difficulties occur between management and employees. In order that employees are able to work to their optimum performance, and that the problems do not turn into bigger issues, suitable ways of dealing with them need to be devised before they occur (Foot \& Hook, 1998). Needless to say, a fair degree of predictable behaviour is need from individual(s) for the achievement of organisational goals 
and objectives. One of the means in ensuring decorum, progress, and effectiveness in an organisation is discipline. Therefore, where there are no proper disciplinary procedures for erring employees, there will be a deviant from the ethos, rules and regulations governing the smooth operation of organisation.

Discipline is one of the most important elements in every organisation. It is generally the backbone of every aspect of individual character because it guides how one speaks, behaves, responds to situations and treats other. Organisations are generally made up of groups of employees who are interdependent, and work together to achieve organisational goals. Thus, they interact with one another on a daily basis to fulfil their job roles and to contribute effectively to their organisation. However, people enter the workplace with their own unique attitudes; abilities, value and perceptions, and this in, itself can bring conflict in any organisation (Grossett, 1999).

According to Adams (2003), organisation rules and regulations are among the strategies designed to install good conduct on employees just like students in a school. This implies self-control, orderliness, good behaviour and obedience to organisation's authority. Also, on employment, employees are given prospectus, which spell out some of the expectations (Apalia, 2017). These rules and regulations specify in most cases what new employees should do and not do. Despite these expectations, in most cases in Nigerian business organisations, employees break these rules and regulations with wide spread indiscipline acts such as taking of alcoholic drinks, absent from work without permission, and participating in frequent strikes, these among others affect employees' performance.

Agba, Ochimana and Abubakar (2013) affirms that when things are put in proper place, the employees will have no reason not to put in their best for the achievements of the set goals and objectives of the organisation. However, the behaviour of every human being is functioning of his/her certain needs, and motives. Because of the unpredictable nature of man, it is not easy to determine what in the nature of human beings make them behave in certain ways (Schein, 1983; Knight \& Ukpere, 2014). To resolve conflict between individuals and groups, between groups and management, and to ensure a harmonious work environment, managers, supervisors and other leaders apply disciplinary action/ procedure to prevent escalation of bad behaviour and to maintain industrial peace (Vonai, 2013). Disciplinary action, in its essence, is designed to correct behaviour and to maintain balance in the employment relationship (Grogan, 2009). This supports the assertion of Rao (2009) who posits that when undesirable behaviour or actions are noticed in the workplace, it is thus the prerogative of leaders and managers to correct this behaviour and establish more acceptable norms or standards than those being corrected. Thus, it is needless to say that these efforts should be conducted by HR managers or professionals. Therefore, discipline and its subsequent rules and procedures form an integral part of the employment relationship between employer and employee. 
In Nigerian business organisations, it is a rare manager who has a good, intuitive sense of how to investigate employee misconduct. Too frequently investigations are conducted in a haphazard manner, worse still; they overlook one or more investigative concerns. In conducting an employee investigation, it is important to be objective and to avoid the assumptions, suppositions, and biases that often surround discipline cases. This article, therefore, attempts to explain why there is an increase in misconducts and non-compliance in the workplace amidst comprehensive disciplinary actions/procedure. Thus, the article intends to evaluate the effective and fairness of disciplinary procedure on employee performance and most importantly, the role of $\mathrm{HR}$ managers in discipline handling.

\section{CONCEPT AND NATURE OF DISCIPLINE}

The Shorter Oxford English Dictionary defines discipline in the following ways: to subject to discipline is to educate or train, to bring under control. The term discipline can be used in various ways. It can be referred to as self-discipline, where an individual, as a result of practice and training, works in an ordered, self-controlled manner. This is self-control or voluntary submission, arising from the inner motives of the individual to organise and regulate his/her behaviour in a systematic and acceptable manner. Increase in self-discipline often reduces the need for supervisory control in the workplace. Discipline can also be used to refer to esprit-de-corps. This is concerned with orderly behaviour within an organisation, similar to self-discipline. It involves a spirit of loyalty and dedication or devotion to group norms and values, which unite and integrate the members of a group who are engaged in a common endeavour. In an organisation, it calls for monitoring of group behaviour and control of group performance to ensure compliance with rules and to correct deviations (Torrington \& Hall, 1995). Moreover, it can refer to a judicial process. This involves the monitoring and enforcement of obedience, and applying established rules so as to avoid occurrence of undesirable and unacceptable acts. It assumes that in group efforts, some individuals will occasionally break established rules. Thus, some processes must be put in place for deviations to be brought to light, and the need for improvement ensured by applying some form of punishment or sanctions (Torrington \& Champam, 1979; Torrington \& Hall, 1995).

According to Byars and Rue (2009), discipline is an action taken against an employee when the employee has violated an organisation's rule or when employee's performance has deteriorated to the point where corrective action is needed. Dumisan (2002) defined discipline as a system of rules and mechanism for ensuring that disciplinary codes are followed. This implies that every organisation has its rules and regulations (dos and don'ts). Observance of these sets of rules and regulations in itself is discipline. Bohlnader and Snell (2007) define discipline as training that 'corrects moulds, or perfects knowledge, 
attitudes, behaviour, or conduct." This definition tries to take away the thinking by many people who look at 'discipline' as something aimed at an individual for negative reasons or that the action is meant to make someone feel the pain. It is obvious from the above definitions, that the concept of discipline has three basic meanings:

1. Treatment that punishes;

2. Orderly behaviour in an organisation setting;

3. Training that moulds and strengthens desirable conduct or corrects undesirable conduct and develops self-control.

To some managers, discipline is synonymous with force. They equate the term with the punishment of employees who violate rules or regulations. Other managers think of discipline as a general state of affairs. That is, a condition of orderliness in which employees conducts themselves according to standards of acceptable behaviour. Discipline viewed in this manner can be considered positive when employees willingly practice self-control and respect organisational rules. The third meaning considers discipline a management tool used to correct undesirable employee behaviour. Discipline is applied as a constructive means of getting employees to conform to acceptable standards of performance. In the context of this article, discipline is thus viewed as a way to correct poor employee performance. Discipline should be seen as a method of training employees to perform better or to improve their job attitudes or work behaviour. Therefore, when taken action against employees, disciplinary action should never be thought of as punishment. Discipline can embody a penalty as a means of obtaining a desired result. However, punishment should not be the intent of disciplinary action. Rather, discipline must have as its goal the improvement of the employee's future behaviour. To apply discipline in any other way - as punishment or as a way of getting even with employees can only invite problems for management, including possible wrongful discharge suits.

\section{NEED FOR DISCIPLINARY ACTION}

The need for discipline lies in the desire of an organisation to direct its employees towards acceptable standards of behaviour. Discipline is indispensable to management control. It assists management in the maintenance of harmonious relations in the workplace (Pigrors \& Myers, 1977; Idris \& Alegbeleye, 2015; Dzimbiri, 2016). Nova (2012) posits that some would use disciplinary action to correct wrong behaviour while others would use it to humiliate the offenders and not to train them. This is where they display a narrow thinking that disciplinary action is to be punitive; this gives a negative idea of the whole good purpose of it. Disciplinary action therefore ensures just and equal treatment of employees, efficient and effective communication, and serves as a tool or device for enforcing organisational standards (Apalia, 2017). Also Van Der Bank and Strumpher (2007) added that the role of discipline in the workplace is to ensure that 
individuals contribute effectively and efficiently to the goals of the organisation. Production of goods and the provision of services would be impeded if, for example, employees were free to stay away from work when they please, to work at their own pace, to fight with their fellow employees or to disobey their employer's instructions. Hence, it is the prerogative and duty of employers or management to ensure that their employees adhere to reasonable standards of efficiency and conduct.

Awodele-Fayomi (2015) observes that disciplinary action is aimed at improving performance of the employee by ensuring that employee behaviour is consistent with the organisation's goals. It encourages employees to behave in a manner that makes them adhere to rules and regulations. Similarly, Cole (2002) holds that the advantages of disciplinary action are three folds; it contributes to the stability of the workforce, labour turnover is minimized, and it promotes productivity. Dzimbiri (2016) adds that disciplinary action is an appropriate method for supervisors to use when correcting employees' misdeeds and helping them attain performance levels that meet employers' expectations. In view of the above, it can be deduced that the purpose of discipline is to correct behaviour. It is not designed to punish or humiliate an employee. Often, a positive approach may solve the problem without having to discipline. For example, if unacceptable behaviour is a persistent problem or if the employee is involved in a misconduct that cannot be tolerated, for instance, poor performance, absenteeism, insubordination, theft, and other misconduct, management may use discipline to correct the behaviour. Therefore, its major purpose is to ensure that employee behaviour is consistent with the firm's goals, and encourage employees to comply with established standards and rules, so that infractions do not occur (preventive discipline). It also seeks to discourage further infraction of rules, so that future acts will be in compliance with desired standards (corrective discipline). Hence, workplace discipline is a teaching and improvement tool or training that moulds behaviour and strengthens desirable conduct.

\section{APPROACHES TO DISCIPLINARY ACTION}

If a thorough investigation shows that an employee has violated some organisation rule, disciplinary action must be imposed. Three approaches to disciplinary action are preventive discipline, progressive discipline and positive discipline.

Preventive Discipline: Discipline is regarded as preventive when organisation design and put in place programmes or measure that discourage or dissuade organisational members from coming late, absenteeism, redundancy, disobedience to superior officer, insubordination among others. Preventive discipline is meant to prevent violation or deviation. Therefore, it is usually stated expressly without ambiguity and in simple terms for the high and the low in the organisation to understand the message. For example, "Loitering during work 
hours is prohibited" (Muhammad, 2013). However, for preventive discipline to be effective, managers must create an environment of openness and honesty, one in which employees feel comfortable sharing even negative information and are appreciated for doing so in a timely fashion.

Progressive Discipline: Generally, discipline is imposed in a progressive manner. By definition, progressive discipline is the application of corrective measures by increasing degrees (Bohlander \& Snell, 2007). Progressive discipline is designed to motivate an employee to correct his or her misconduct voluntarily. The technique is aimed at nipping the problem in the bud, using only enough corrective action to remedy the shortcoming. However, the sequence and severity of the disciplinary action vary with the type of offense and the circumstances surrounding it. Because each situation is unique, a number of factors must be considered in determining how severe a disciplinary action should be. The typical progressive discipline procedure includes four steps. From an oral warning (or counselling) to subsequent unsatisfactory behaviour or performance will not be tolerated, the action may progress to a written warning, to a suspension without pay, and ultimately to discharge. The "capital punishment" of discharge is utilised only as a last resort.

Positive Discipline: Positive discipline or non-punitive disciple is based on the concept that employees must assume responsibility for their personal conduct and job performance. By definition, positive discipline is a system of discipline that focuses on early correction of employee misconduct, with the employee taking total responsibility for correcting the problem (Bohlander\& Snell, 2007). Nothing is imposed by management; all solutions and affirmations are jointly reached. HR managers often describe positive discipline as "non-punitive discipline that replaces threats and punishment with encouragement. The positive discipline is implemented in three steps. The first is a conference between the supervisor and the employee. The purpose of this meeting is to find a solution to the problem through discussion, with oral agreement by the employee to improve his or her performance. The supervisor refrains from reprimanding the employee or threatening him or her with further disciplinary action. Supervisors may document this conference, but a written record of this meeting is not placed in the employee's file unless the misconduct occurs again. If improvement is not made after this first step, the supervisor holds a second conference with the employee to determine why the situation agreed to in the first conference did not work. At this stage, however, a written reminder is given to the employee. This document states that new or repeated solution to the problem, with an affirmation that improvement is the responsibility of the employee and a conviction of continued employment (Nova, 2012). However, when both conferences fail to produce the desired results, the third step is to give the employee a one-day decisionmaking leave (a paid leave). The purpose of this paid leave is for the employee to decide whether he or she wishes to continue working for the organisation. The organisation pays for this leave to demonstrate its desire to retain the employee. Therefore, employee given a decision-making leave is instructed to return the 
following day with a decision either to make a total commitment to improve performance or to quit the organisation. If a commitment is not made, the employee is dismissed with the assumption that he or she lacked responsibility toward the organisation.

\section{FUNDAMENTAL CAUSES OF DISCIPLINARY ACTION}

Disciplinary actions usually come out of dissatisfaction of the manager with flouting of work rules, and intentional deviation from role prescriptions by an employee. Formal behaviours that may elicit disciplinary actions vary from organisation to organisation, but often depend on the size, complexity, nature of product, management policies, materials dealt with, processes involved and clientele of the organisation. Common causes of the need for disciplinary action include the following:

\section{Attendance Problems}

1. Unexcused absence from work;

2. Chronic absenteeism or irregular attendance;

3. Excessive lateness and tardiness;

4. Leaving office without permission;

5. Time recording offences.

\section{Dishonesty and Related Problems}

1. Falsification of company records or complicity with such acts;

2. Altering or use of forged documents;

3. Entering into unholy alliance with others;

4. Stealing or complicity in the act;

5. Malicious/wilful damage to company property;

6. Working for competing firms;

7. Espionage or complicity in such act;

8. Collusion with the aim of defrauding the firm;

9. Fraud or complicity in such act;

10. Deliberate faking of records/payment bills;

11. Disloyalty, including failure to disclose knowledge of misconduct committed or about to be committed against the firm.

\section{III.On-the-Job Behaviour Problems}

1. Loafing or sleeping on duty;

2. Insubordination;

3. Fighting a customer or staff while on duty;

4. Intoxication at work/smoking in restricted area;

5. Wilful breach of safety rules;

6. Delay in performing official duties, so as the elicit gratification; 
7. Gambling;

8. Failure to report injuries/damages;

9. Abusive or threaten language to supervisor;

10. Sexual harassment;

11. Carelessness/horseplay;

12. Possession of narcotics or alcohol.

\section{Work Performance Problems}

1. Failure to meet established production requirement;

2. Failure to complete work assignments;

3. Producing substandard products or services.

It would be impossible to itemise fully the range of behaviours that might result in disciplinary action being taken. Moreover, many employers have divided offences into two categories, depending on the seriousness with which they are viewed within the organisation. They list issues that they regard as disciplinary offences, and then itemise some as gross misconduct that they consider to be more serious.

\section{DISCIPLINARY PROCEDURE}

A procedure is a series of steps or stages through which a matter may be processed towards a decision or conclusion. Armstrong (2010) presents a general disciplinary procedure from which organisations can draw theirs from. It begins with the informal warning which is given to the employee in the first instance or instances of minor offences. This warning is administered by the employee's immediate supervisor. Secondly, a formal written warning letter is given to the employee in the first instance of a serious offence or after repeated instances of minor offences. Then further disciplinary action is given to an employee if, despite previous warnings, he or she still fails to reach the required standards in a reasonable period of time. This disciplinary action could be dismissal. Additionally, an employee can be summarily dismissed only in the event of gross misconduct as defined in the company rules. However, disciplinary action should not be taken against an employee unless the following conditions are met: first, it is undertaken only in cases where good reason and clear evidence exists. Second, it is appropriate to the nature of the offence that has been committed. Third, it is demonstrably fair and consistent with previous action in similar circumstances. Fourth, it takes place only when employees are aware of the standards that are expected of them or the rules with which they are required to conform. Fifth, employees are allowed the right to be represented by a representative or colleague during any formal proceedings. Sixth, employees are allowed the right to know exactly what charges are being made against them and to respond to those charges. Lastly, employees are allowed the right of appeal against any disciplinary action (Armstrong, 2010). 
In addition, Nova (2012) argues that disciplinary procedures set out the stages through which any disciplinary action should proceed. The procedure provides an acceptable mechanism within which management may exercise control over employees when their performance or behaviour does not reach the required standards (Dzimbiri, 2009). To be deemed fair, disciplinary procedures should be used consistently and have uniform standards in the approach to disciplinary employees. This helps avoid confusion and possible legal implications cause by inconsistent and sometimes harsh disciplinary decisions that are deemed unfair and unjust. This supports the assertion of Stone (2005) who posits that an inconsistent and unplanned approach to imposing discipline leads to legal action being taken against the organisation. A disciplinary procedure should specify the following key elements: rules, offences, penalties, procedural steps, and appeal procedures.

Rules: An ideal disciplinary procedure provides for working rules and arrangements that are tailored to the specific needs of the organisation. For example, the minimum standards for the performance or conduct of employees are referred to as work rules. Most employers state those rules in the organisation's handbook or disciplinary procedure code book. Typically, work rules specify standards affecting issues, such as listed below:

1. Working hours;

2. Time for break;

3. Safety rules and reporting of injuries;

4. Reporting of lateness, absence due to illness;

5. Designated areas for smoking;

6. Standards of personal conduct;

7. Theft, fraud or dishonest;

8. Immoral conduct;

9. Sabotage of company material or property;

10. Falsification of records (Foot \& Hook, 1988).

Offences: When a rule is broken, an offence has been committed. A disciplinary procedure must seek to identify offences which would attract disciplinary action. In practice, offences are commonly classified into minor, serious, or gross misconduct.

Penalties: These are measures for dealing with specific offences. They may also be referred to as 'negative rewards.' The objectives of penalties are: to reform offenders, deter would-be offenders, and maintain the integrity of the organisation. Another way of putting it, is to see penalties as educative, corrective and punitive. Most formal disciplinary processes often employ is called 'progressive discipline.' The step-by-step processes include:

1. Warning - oral or written (informal/formal);

2. Suspension and downgrading;

3. Fines, withholding annual increment or promotion; 
4. Retirement, outright dismissal or termination of appointment (Foot \& Hook, 1988).

Invariably, penalties for minor offences are aimed at educating and counselling employees, and giving them opportunity to learn and adjust.

Procedural Steps: These are usually guidelines which set out the operational drills, associated with the imposition of penalties for offences, and for appealing and challenging the penalties. The procedural steps will involve the following:

1. Specify who has the responsibility and authority to make relevant decision - Immediate Superior, Department Managers, General Manager, Managing Director, HR Manager, Disciplinary Committee, Appeals Committee, etc.

2. Provide for a right of appeal to a level of management not previously involved in the action.

3. Specify the mode of imposing various penalties which must be proportionate to offences or misconduct committed (Cole, 1986).

Appeal Procedures: This section of the disciplinary procedure should indicate what the employee should do, if he or she is not happy with the action taken against him or her. There should be a clear appeal procedure, with time limits for the submission of appeal stated. It would be too important to leave disciplinary decisions solely to the discretion of immediate superior or committee, no matter how powerful they are, without providing opportunity for an appeal. Therefore, it is essential that there be some ways for employees to initiate a review. The following channels of appeals against disciplinary actions are usually adopted:

1. Up-the-line Approach: Here, the employee should have the right to appeal, first to the supervisor, and then the step-by-step process may continue up the line, through the Departmental Head, HR Department, General Manager, and the Managing Director or Committees.

2. HR Director's Intervention: In this approach, the appellant would simply appeal to the HR Director for intervention and possible settlement.

3. Disciplinary and Appeal Committee: In organisations, this is the committee which is given authority to receive, hear and settle employee's appeal arising from disciplinary action. The committee could either overrule a line manager's decision or uphold it (Torrington \& Hall, 1995; Torrington, Hall \& Taylor, 2008).

\section{COMMON DISCIPLINARY PROBLEMS}

According to Torrington et al. (2008), some of the disciplinary problems faced in several workplaces among others include: first, negligence, which is defined as failure to do the job properly. This is different from incompetence because the assumption here is that the employee can do the job properly but has 
not; second, unreliability, which is failure to attend to work as required, such as reporting late for work and absenteeism. Third, insubordination, this is refusal to obey an instruction or deliberate disrespect to someone in a position of authority. Fourth, interference with the rights of others, this covers a range of behaviours that are socially unacceptable. This involves fighting, which is clearly identifiable, harassment and intimidation which may be a bit difficult to establish. Fifth, theft, this is clear cut aspect of behaviour that is unacceptable especially when it is from an employee and lastly, safety offences, these are aspects of behaviour that can cause accidents or hazards. Nova (2012) described disciplinary problems as those acts that are contrary to the rules and regulations of the workplace. They can be caused or solved by either management or employees themselves. Torrington $e t$ al. (2008) asserts that a disciplinary problem is as likely to be solved by management action as it is likely to be solved by employee actions.

There are a number of challenges associated with discipline. First, workers are unhappy, managers spend time on each disciplinary case, interpersonal relationships between managers and employees suffer and eventually the overall productivity of the company drops (Cropanzano, Bowen \& Gilliland, 2007). Since this method mainly focuses on the use of threats or penalties thereof, what it does is forcing the employees to leave up to the expectations of the organisation (Dzimbiri, 2009). Secondly, the use of punishments and penalties may cause anger, apathy, resentment and frustration on the employees' side and severally affect production (Rao, 2009; Mgbemena, Mbah \& Ejike, 2015; Dzimbiri, 2016). Third, the penalty-driven disciplinary system usually makes the manager a 'bad person.' Therefore, most managers are reluctant to punish employees because it makes them feel like they are wrong. Instead, they tend to wait until a small behaviour turns into a crisis (Dzimbiri, 2016). Fourth, employees on the other hand see punishment as personal attack, the manager as a dispenser of punishment and therefore stop communicating with superiors (Rao, 2009; Apalia, 2017). Fifth, progressive discipline only generates compliance and not commitment (Decenzo \& Robbins, 2007). Some HR professionals according to Bohlander and Shell (2007), believed that progressive discipline has certain flows, including its intimidating and adversarial nature that prevent it from achieving the intended purpose. Therefore, effective discipline should come from self-discipline in which an employee changes and reinforces his/her own behaviour without much external influence (Positive discipline).

\section{IMPACT OF OBJECTIVE DISCIPLINARY ACTIONS ON EMPLOYEES' PERFORMANCE}

Nwachukwu (2009) observes that management's inability to enforce discipline can be reason for employees' job dissatisfaction, low morale and consequently low productivity. All forms of discipline, however rigid are to prevent the employees from breaking the rule. Discipline seldom compels 
good behaviour; successful discipline induces the employee to control himself by avoiding proscribed action (Mgbemena et al., 2015). When seeking reasons for unsatisfactory behaviour, supervisors or managers must keep in mind that employees may not be aware of certain work rules. Before initiating any disciplinary action, therefore, it is essential that supervisors or managers determine whether they have given their employees careful and thorough orientation in the rules and regulations relating to their jobs. Unfortunately, in Nigerian business organisations, some supervisors or managers try to build a case to justify their corrective actions only after they have decided that a particular employee should be discharged. In the opinions of Torrington and Hall (2004), disciplinary action can be punitive rather than corrective depending on the disposition of the person who is using it and the management style in the organisation. They remarked that fair treatment produces better result because when rule violations are enforced in an inconsistent manner, the rule loses its impact. Consequently, morale will decline and employees will question the competence of management because productivity will equally drop as a result of the employees' perceived insecurity and anxiety.

Therefore, when discipline becomes selective, there is bound to be crisis in the organisation which surely affects performance both at individual and organisational level. In the light of the above, discipline is understood to be a means of correcting or punishing misdeed in an organisation. But while this observation is correct and acceptable, it must be carried out in a manner that in every situation, justice will not only be done but will be seen to have been done. This implies that discipline should be imposed without generating resentment. Therefore, sound and effective disciplinary system in an organisation should be immediate, consistent, impersonal, prior warning and notice acquaintance or knowledge of rules - timely action-fair and just action. These ultimately lead to greater productivity and improved performance.

\section{ROLE OF HR MANAGERS IN DISCIPLINE HANDLING}

The rights of managers to discipline and discharge employees are increasingly limited. There is thus a great need for managers at all levels to understand discipline procedures. Disciplinary action taken against an employee must be for justifiable reasons, and there must be effective policies and procedures to govern its use. Such policies and procedures assist those responsible for taking disciplinary action and help ensure that employees will receive fair and constructive treatment. Equally important, these guidelines help prevent disciplinary action from being voided or reversed through the appeal system. A major responsibility of the HR department is to develop, and to have top management approve, its disciplinary policies and procedures. The HR department is also responsible for ensuring that disciplinary policies, as well as the disciplinary action taken against employees, are consistent with the labour agreement (if one exists) and conform to current laws. 
Discipline is a sensitive issue requiring skilful handling, and in many organisations, it has traditionally become a function that has been left to HR managers. This has been partly due to the fact that HR managers were more likely to be trained in skilful handling of sensitive interpersonal issues, but also many line managers or supervisors were often unwilling to handle issues that might result in their unpopularity and cause difficulties in maintaining a suitable relationship with someone they had to work with on a daily basis. However, this attitude is said to be changing as more and more HR functions are being devolved to line management. Immediate supervisors or line managers in many organisations are nowadays expected to handle disciplinary matters that arise in their sections, at least, in the early stages. This supports the assertion of Bohlander and Snell (2007) who posits that the primary responsibility for preventing or correcting disciplinary problems rests with the employee's immediate supervisor or line manager. This person is best able to observe evidence of unsatisfactory behaviour or performance and to discuss the matter with the employee. Should discipline become necessary, the employee's immediate supervisor or line manager is the logical person to apply the company's disciplinary procedure and monitor employee's improvement?

The HR managers still have several important roles to play when compare with the immediate supervisors or line managers in handling of sensitive interpersonal issues. They should devise the disciplinary procedure, provide specialist advice, ensure that everyone is aware of and acts consistently with the procedures. In addition to these, they are to monitor the effectiveness of the procedures and ensure that changes in policies are brought about when necessary.

\section{THEORETICAL FRAMEWORK}

The theory upon which this article was anchored is Skinner' Reinforcement theory propounded in 1974. The choice of the theory was informed by its relative importance to the phenomenon understudy and can help in explaining the subject matter. Reinforcement theory expresses that belief that changes in behaviour take place as a result of an individual's response to events or stimuli and the ensuring consequences (rewards or punishment). Individuals can be conditional to repeat the behaviour by positive reinforcement in the form of feedback and knowledge of result (Skinner, 1974). Reinforcement theory by Skinner provides a technical description and application of discipline (Werner, 2007). According to this, learning needs to take place before desired behaviour can occur. In this context, learning is defined as a situation where behaviour is influenced by the consequences thereof. According to Werner (2007), positive reinforcement, negative reinforcement, and punishment are examples of this learning process. As for Luthans and Kreitner (1985), positive reinforcement would constitute the consistent presentation of something desirable (for instance, recognition). On the other hand, negative 
reinforcement defined as the reinforcement of behaviour that reduces negative situations (for example, shouting at someone where the shouting only stops after compliance). And punishment involves an undesirable action towards a person (for example, stopping the salary of an absent worker). Skinner (1974) argued that creating pleasing consequences to follow specific forms of behaviour would increase the frequency of that behaviour. He demonstrated that people will most likely engage in desired behaviours if they are positively reinforced for doing so; that rewards are most effective if they immediately follow the desired response; and that behaviour that is not rewarded, or is punished, is less likely to be repeated.

Therefore, reinforcement strengthens behaviour and increases the likelihood that it will be repeated. In this regard, managers in both the public and private sectors are advised to make use of different forms of disciplinary measures starting from the mildest to the most severe such as warnings (i.e., verbal, written and final written); suspensions (with or without remuneration and reduction in annual salary); withholding or determent of increment; rehiring; transfer, demotion; termination, discharge from service or compulsory retirement; and dismissal are some of the options mentioned (Grossett, 1999; Victor \& Maurice, 2012; Vonai, 2013); Knight \& Ukpere, 2014; Awodele-Fayomi, 2015; Idris \& Alegbeleye, 2015; Dzimbiri, 2016; Apalia, 2017).

This article recommends a positive discipline, which requires a cooperative environment in which the employee and the supervisor engage in joint discussion of problem solving to resolve incidents of employee irresponsibility or where counselling sessions between the employee and the supervisor or line manager replaces threats and punishment with encouragement.

\section{CONCLUSION}

Discipline is management action that encourages and ensures compliance with laid-down rules and regulations, governing the smooth operation of an organisation. Discipline can only be a means of correcting or punishing misdeed in an organisation only if management learn to maintain discipline by applying standards in a consistent, fair and flexible manner. The article recommended that three components are necessary for the effective maintenance of a disciplinary procedure in an organisation. The components include consultation or negotiation, communication with everybody concerned regarding the exact way in which the system operates, and training of the individuals involved in a disciplinary process. In addition, the application of discipline should be immediate, with warning, consistent and impersonal. The key role of HR managers therefore, are to devise the disciplinary procedure, provide specialist advice, ensure that everyone is aware of and acts consistently with the procedures, monitor the effectiveness of the procedures and ensure that changes in policies are brought about when necessary. 


\section{REFERENCES}

Adams, N. (2003). Secondary School Management today. London: Hutchinson Ltd.

Agba, M. S., Ochimana, G. E., \& Abubakar, Y. I. (2013). Public Service ethics and the fight against corruption in Nigeria: A critical analysis. International Journal of Public Administration and Management Research, 2(1), 112-118.

Apalia, E. A. (2017). Effects of discipline management on employee performance in an organization: The case of country education office human resource department, Turkana County. International Academic Journal of Human Resources and Business Administration, 2(3), 1-18.

Armstrong, M. (2009). Armstrong's Handbook of Human Resources Management Practice. London: Kogan Page.

Armstrong, M. (2010). Essential human resource management practice: A guide to people management. New Delhi: Replika Press Ltd.

Awodele-Fayomi, I. O. (2015). Managing discipline problems in the contemporary Nigerian civil service for sustainable national development. Journal of Economics and Sustainable Development, 6(17), 137-147.

Bohlander, G., \& Snell, S. (2007). Managing Human Resources. United Kingdom: South-Western Ltd.

Byars, A., \& Rue, M. (2009). Reward management: A handbook of remuneration strategy and practices. London: Kogan Page.

Cole, G. A. (1986). Management theory and practice. London: D. P. Publication Ltd.

Cole, G. A. (2002). Personnel and human resources Management. United Kingdom: South-Western Ltd.

Cropanzano, R., Bowen, D. E., \& Gilliland, S. W. (2007). The management of organizational Justice. Academy of Management Perspective. 11, 34-48.

Decenzo, D. A., \& Robbins, S. P. (2007). Personnel/Human Resource management. New Delhi: Prentice Hall.

Dumisan, I. E. M. (2002). Impact of discipline on Learner Performance. Unpublished Master's thesis.

Dzimbiri, G. (2017). The effectiveness, fairness and consistency of disciplinary actions and procedures within Malawi: The case of the civil service. IOSR Journal of Business and Management, 18(10), 40-48.

Dzimbiri, L. (2009). Trade union under the one-party and multiparty political system in Malawi. Malawi Journal of Social Science, 4(1), 8-17.

Foot, M., \& Hook, C. (1988). Introducing Human Resources Management. London: Longman.

Grogan, J. (2009). Workplace Law. Oxford: Oxford University Press.

Grossett, R. (1999). Discipline and dismissal: A practical guide for South African managements. Johannesburg: Thomson Publishers.

Idris, S., \& Alegbeleye, G. I. (2015). Discipline and organization effectiveness: A study of Nigeria customs service. Review of public Administration and Management, 4(8), 88-106.

Knight, S., \& Ukpere, W. I. (2014). The effectiveness and consistency of disciplinary actions and procedures within a South African Organisation. Mediterranean Journal of Social Sciences, 5(4), 589-596.

Luthans, F., \& Kreitner, R. (1985). Organisational behaviour: Modification and beyond. Glenview: Scott Foresman.

Mgbemena, G. C., Mbah, S. I., \& Ejike, D. C. (2015). Impact of effective employee performance management on organizational productivity: A study of Anambra 
State civil service system, Nigeria. The International Journal of Business \& Management, 3(11), 183-196.

Muhammad, A. (2013). Ethics and accountability in Nigerian public service: Its collapse and the way forward. Academic Journal of Interdisciplinary Studies, 2(5), 117-120.

Nova, S. (2012). The relationship between employment arbitration and workplace dispute resolution. Ohio State Journal of Dispute Resolution, 16(3), 643-668.

Nwachukwu, C. C. (2009). Human Resource Management. Port Harcourt: David Stone Publishers.

Pigrors, P., \& Myers, C. S. (1977). Personnel Administration. New York: McGraw-Hill.

Rao, A. (2009). Distressed, grievance procedures and their rehabilitation. Institute of Industrial Relations, 5(1), 209-304.

Schein, E. (1983). Organisational Psychology. New Delhi: Prentice Hall.

Skinner, B. F. (1974). About behaviourism. London: Cape.

Stone, J. (2005). Management control: The role of discipline. London: Association of Chartered and Certified Accountants.

Torrignton, D., Hall, L., \& Taylor, S. (2008). Human Resource Management. Essex: Prentice Hall.

Torrington, D., \& Hall, L. (1995). Personnel Management: HRM in action. London: Prentice Hall.

Torrington, D., \& Hall, L. (2004). Disciplinary measures: Organisation's means of enforcing compliance. Journal of Management Sciences, 3(2), 121-129.

Torrington, D., \& Champam, J. (1979). Personnel Management. London: Prentice Hall.

Van Der Bank, L., \& Strumpher, J. (2007). Perceived fairness of disciplinary procedures in the public sector: An exploratory study. SA Journal of Human Resource Management, 6(2), 1-8.

Victor, O. E., \& Maurice, A. C. (2012). Influence of staff discipline and attitude to work on job satisfaction of lecturers in tertiary institution in Cross River State. Public Policy and Administration Research, 2(3), 25-33.

Vonai, C. (2013). Management of discipline for good performance: A theoretical perspective. Online Journal of Social Sciences Research, 2(7), 214-219.

Werner, A. (2007). Organisational behaviour: A contemporary South African perspective. Pretoria: Van Schaik Publishers. 